\title{
Copper Toxicity on Photosynthetic Responses and Root Morphology of Hymenaea courbaril L. (Caesalpinioideae)
}

\author{
Daniele Maria Marques • Valdir Veroneze Júnior • \\ Adriano Bortolotti da Silva • \\ José Ricardo Mantovani • Paulo César Magalhães • \\ Thiago Corrêa de Souza
}

Received: 10 November 2017 / Accepted: 28 February 2018/Published online: 11 April 2018

(C) Springer International Publishing AG, part of Springer Nature 2018

\begin{abstract}
Copper $(\mathrm{Cu})$ is a micronutrient essential for plant development. However, in excess, it is toxic to plants and may cause various physiological and morphological changes. The study of the growth of plants exposed to excess $\mathrm{Cu}$ is important for the development of phytoremediation programs and for understanding the mechanisms involved in the tolerance of this metal. In this context, the objective of this research was to evaluate the effect of excess copper on photosynthetic responses and root morphology of Hymenaea courbaril L. Biometric measurements, gas exchange, root morphology, and $\mathrm{Cu}$ content in tissues and indices (TI and TF) were assessed, involving metal content and biomass. Up to a concentration of $200 \mathrm{mg} \mathrm{kg}^{-1}, \mathrm{Cu}$ favored growth, gas exchange, and root morphology of the plants under study. At a higher concentration $\left(800 \mathrm{mg} \mathrm{kg}^{-1}\right)$ in the soil, it affected plant growth and caused a decrease in photosynthetic rate. Biochemical limitations in photosynthesis were observed, as well as
\end{abstract}

D. M. Marques $(\bowtie) \cdot$ V. Veroneze Júnior $\cdot$ T. C. de Souza Institute of Nature Sciences - ICN, Federal University of Alfenas-UNIFAL-MG, Street Gabriel Monteiro, P. O. Box 700, Alfenas, MG 37130-000, Brazil

e-mail: danimarques.bio@gmail.com

A. B. da Silva · J. R. Mantovani

Section of Agricultural Sciences, University José do Rosário

Vellano-UNIFENAS, Rod. MG 39 km 0, Alfenas, MG

37130-000, Brazil

P. C. Magalhães

Maize and Sorghum National Research Center, P. O. Box 151,

Sete Lagoas, MG 35701-970, Brazil lower maximum net photosynthetic rate $\left(A_{\max }\right)$, respiration rate in the dark $\left(R_{\mathrm{d}}\right)$, light compensation point (LCP), light saturation point (LSP), and apparent quantum yield $(\alpha)$, when exposed to excess $\mathrm{Cu}$. Root length, surface area, mean diameter, root volume, dry biomass, and specific root length decreased with high $\mathrm{Cu}$ concentrations in the soil. $\mathrm{Cu}$ was accumulated in the roots as a mechanism of tolerance to the excess of this metal in order to preserve the most metabolically active tissues present in the leaves. At a concentration of $800 \mathrm{mg} \mathrm{kg}^{-1}$, copper also caused inhibition of the root system. Plants of $H$. courbaril showed tolerance to excess $\mathrm{Cu}$ in the soil and can be indicated for the recovery of areas contaminated with this metal.

Keywords Heavy metal - Gas exchange - Specific root length $\cdot$ Root anatomy $\cdot$ Phytoremediation $\cdot$ Copper tolerance $\cdot$ WinRHIZO

\section{Introduction}

Copper $(\mathrm{Cu})$ is a micronutrient essential for plant development. However, in excess in the soil, it becomes phytotoxic to plants, interfering in innumerable physiological processes (Yruela 2013; Küpper and Andresen 2016). The synthesis of photosynthetic pigments, cell membrane permeability, homeostasis, and plant nutrient balance is altered at high $\mathrm{Cu}$ concentrations (Adrees et al. 2015; Gautam et al. 2016). Excess $\mathrm{Cu}$ ions in plants cause disturbances in photosynthesis, which can result in oxidative stress, with increasing reactive 
oxygen species (ROS), reducing carbon fixation, and reducing or inhibiting plant development (Küpper and Andresen 2016). Exposure to $\mathrm{Cu}$ stress leads to remodeling in root morphology (Cai et al. 2014), since the root is the first organ to come into contact with the contaminant. The use of digital images of roots is an important parameter for analysis of root development. However, it is worth mentioning that there are few studies on the root morphology of native species and this often occurs due to the difficulty in analyzing this underground organ. High copper concentrations reflect on a reduction in root biomass, as well as in shoot biomass (Feigl et al. 2013).

The knowledge of physiological, biochemical, and morphoanatomic responses of plants, when exposed to heavy metals, is of great importance for the recovery of contaminated areas. Phytoremediation and the physiological processes involved have aroused worldwide interest (Ent et al. 2013), but morphological and physiological responses are still poorly understood in forest species. The use of trees in phytoremediation programs has advantages, once the metal remains immobilized in plant tissues for a longer period and the roots present a barrier against contaminant leaching. The species Hymenaea courbaril L. (Caesalpinioideae) is native to Brazil and has qualities in the recovery of degraded areas due to the wide distribution of this species and the tolerance and adaptation to a variety of environments. However, its tolerance and mechanisms of adaptation to copper stress are not yet known. In this context, the objective of this research was to evaluate the effect of excess copper on photosynthetic responses and root morphology of Hymenaea courbaril L.

\section{Material and Methods}

\subsection{Experimental Conditions}

The experiment was conducted at the Institute of Agricultural Sciences of Universidade José do Rosário
Vellano (UNIFENAS), in Alfenas, MG, Brazil, located at $21^{\circ} 25^{\prime} 45^{\prime \prime} \mathrm{S}, 45^{\circ} 56^{\prime} 50^{\prime \prime} \mathrm{W}$ and altitude of $881 \mathrm{~m}$. The experimental design was in randomized blocks (DBC), consisting of five copper concentrations $\left(\mathrm{CuSO}_{4} \cdot 5 \mathrm{H}_{2} \mathrm{O}\right), 0,100,200,400$, and $800 \mathrm{mg} \mathrm{kg}^{-1}$, and four replicates. The plant material consisted of Jatobá-Hymenaea courbaril L.-plants, with an approximate age of 120 days. The sowing was accomplished in tubes with capacity of $180 \mathrm{~cm}^{3}$, filled with commercial substrate Plantmax ${ }^{\circledR}$ and basic fertilization composed of $3 \mathrm{~kg} \mathrm{~m}^{-3}$ of Yorim Master® $\left(16 \% \mathrm{P}_{2} \mathrm{O}_{5}\right.$, $18 \% \mathrm{Ca}, 7 \% \mathrm{Mg}$ ). Three side dressing fertilizations were carried out at 45, 60, and 90 days after sowing with: $20 \mathrm{~g}$ of $\mathrm{N}$ and $15 \mathrm{~g}$ of $\mathrm{K}_{2} \mathrm{O}$, respectively, with urea and potassium chloride as the source, which were dissolved in 101 of water and applied $10 \mathrm{ml}$ solution per plant.

In the experiment, subsurface soil was used, with the chemical characterization described in Table 1. The substrate used consisted of $360 \mathrm{dm}^{3}$ soil, supplemented with $3.6 \mathrm{~kg}$ earthworm humus, $160 \mathrm{~g}$ limestone, and $230 \mathrm{~g}$ simple superphosphate. Plants of $H$. courbaril were transferred to pots $\left(18 \mathrm{dm}^{3}\right)$, kept in a greenhouse with a plastic cover $(150 \mu \mathrm{m})$, and covered on the sides with a screen (sombrite ${ }^{\circledR} 50 \%$ ). During the experiment, soil moisture was controlled every 2 days, by weighing the pots and replacing the water, to maintain soil moisture at $70 \%$ retention capacity. Thirty days after transplanting seedlings, copper concentrations were applied to the soil surface via solution. Sixty days after copper application, nitrogen fertilization was carried out at a dose of $10 \mathrm{mg} \mathrm{kg}^{-1} \mathrm{~N}$, in the form of urea. The experiment occurred from December 2014 to May 2015.

\subsection{Biometric Measurements}

Six measurements were made for each treatment of height $(\mathrm{H})$ and stem diameter $(\mathrm{SD})$. Measurements were established using a digital caliper and a tape measure at $20,40,60,80,100$, and 120 days of cultivation.

Table 1 Initial chemical characterization of the soil used in the experiment

\begin{tabular}{|c|c|c|c|c|c|c|c|c|c|c|c|c|}
\hline $\mathrm{pH}\left(\mathrm{H}_{2} \mathrm{O}\right)$ & $\begin{array}{l}\mathrm{P} \text { (Mehlich) } \\
\mathrm{mg} \mathrm{dm}^{-3}\end{array}$ & $\begin{array}{l}\mathrm{K} \\
\mathrm{cmo}\end{array}$ & $\begin{array}{l}\mathrm{Ca}^{+2} \\
\mathrm{~m}^{-3}\end{array}$ & $\mathrm{Mg}^{+2}$ & $\mathrm{Al}^{+3}$ & SB & $\begin{array}{l}\mathrm{V} \\
\%\end{array}$ & $\begin{array}{l}\text { M.O. } \\
\text { dag kg }\end{array}$ & $\begin{array}{l}\mathrm{Zn} \\
\mathrm{mg} \mathrm{dm}^{-3}\end{array}$ & ${ }_{3} \mathrm{Fe}$ & $\mathrm{Mn}$ & $\mathrm{Cu}$ \\
\hline 5.7 & 0.4 & 0.2 & 0.5 & 0.3 & 0.1 & 1.0 & 29 & 0.9 & 0.2 & 3.0 & 2.5 & 0.2 \\
\hline
\end{tabular}

$S B$ sum of bases, $V$ base saturation index, M.O. organic matter 


\subsection{Gas Exchange}

Gas exchange parameters were measured using a portable photosynthesis system (IRGA, LI-6400XT, Li-Color, Lincoln, NE, USA) and a chamber with artificial light source (LI-6400-02B RedBlue) at 20, 40, 60, 80, 100 , and 120 days of cultivation after copper application to the soil. Spot measurements were performed in the morning from 9.00 to 11.00 a.m. on a fully expanded leaf in the fourth node counting from the apical region. The parameters evaluated were leaf photosynthesis rate $(A)$, stomatal conductance $\left(g_{\mathrm{s}}\right)$, transpiration $(E)$, concentration of intercellular $\mathrm{CO}_{2}\left(C_{\mathrm{i}}\right)$, water use efficiency $\left(A / g_{\mathrm{s}}\right)$, and carboxylation efficiency $\left(A / C_{\mathrm{i}}\right)$. The measurements were performed on a leaf area of $6 \mathrm{~cm}^{2}$, and the airflow in the chamber was at a $\mathrm{CO}_{2}$ concentration of $380 \mathrm{mmol} \mathrm{mol}^{-1}$. The air was collected from outside the greenhouse, transported to a gallon buffer tank, and then pumped into the chamber. A photon flux density (PPFD) of $1000 \mu \mathrm{mol} \mathrm{m}{ }^{-2} \mathrm{~s}^{-1}$ was used, with blue-red LED light source, and the chamber temperature was $28^{\circ} \mathrm{C}$.

The curves of the net photosynthetic rate $(A)$ in response to the flux of photosynthetically active radiation (PAR) were determined by the same portable photosynthesis system. All measurements were made on the same leaf used for spot measurements in three plants per treatment. The PAR used were 1400, 1000, 800, 200, $100,50,25$, and $0 \mu \mathrm{mol} \mathrm{m} \mathrm{m}^{-2}$ for $5 \mathrm{~min}$ at $28^{\circ} \mathrm{C}$ and at ambient $\mathrm{CO}_{2}$ conditions (approximately $380 \mu \mathrm{mol} \mathrm{mol}^{-1}$ ). The curves were made at four different times 30,60, 90, and 120 days of cultivation. Data referring to the curves were adjusted to the rectangular hyperbolic function: $A=a+\left[\left(A_{\max } \times \mathrm{PAR}\right) /(b+\mathrm{PAR})\right]$, where $A_{\max }$ is the maximum net photosynthetic rate and $a$ and $b$ are coefficients of the equation. Through the curve, maximum net photosynthetic rate $\left(A_{\max }\right)$ was obtained, as well as respiration rate in the dark $\left(\mathrm{R}_{\mathrm{d}}\right)$, measured in leaves adapted to the dark, light compensation point (LCP), and light saturation point (LSP). Apparent quantum yield $(\alpha)$ was estimated by linear regression of the initial region of the curve $(0 \leq \mathrm{PAR} \leq$ $\left.200 \mu \mathrm{mol} \mathrm{m} \mathrm{m}^{-2} \mathrm{~s}^{-1}\right)$, where $A=c+(\alpha \times \mathrm{PAR})$, and $c$ and $\alpha$ are adjustment coefficients.

\subsection{Root Morphology}

For root morphology, three roots were used per treatment at the end of the experiment. After the washing process, the plants were separated into root system and shoot, at the stem-root region. For the morphology analysis of the root system, the image analysis system WinRHIZO Pro 2007a (Regent Instruments, SainteFoy, QC, Canada) was used, coupled to a professional scanner (Epson, Expression 10000 XL, Epson America, Inc., Long Beach, CA, USA), equipped with an additional photon unit (TPU). The procedures for obtaining the images were made according to Souza et al. (2012a). The following characteristics were determined: root length $(\mathrm{RL})(\mathrm{cm})$, root surface area $(\mathrm{SA})\left(\mathrm{cm}^{2}\right)$, root mean diameter (RMD) (mm), and root volume (RV) $\left(\mathrm{cm}^{3}\right)$. Root length was also analyzed through diameter classes ( 0 to $4.5 \mathrm{~mm}$ ) by the same software. The roots were then stored in paper bags and transported to a forced circulation oven at $65^{\circ} \mathrm{C}$ until a constant mass was obtained. Other attributes involving morphological and dry matter data were the following: ratio between root dry matter and shoot dry matter (RDM/SDM, $\mathrm{g} \mathrm{g}^{-1}$ ), specific root length (SRL, $\mathrm{cm} \mathrm{g}^{-1}$ ), root fineness $\left(\mathrm{RF}, \mathrm{cm} \mathrm{cm}^{3}\right.$ ), and root tissue density $\left(\mathrm{RMDe}, \mathrm{g} \mathrm{cm}^{3}\right.$ ).

\subsection{Leaf and Root Anatomy}

Two samples were collected in the region of the middle third of the first fully expanded leaf (from the apex) for leaf anatomy. Each sample consisted of a leaflet. The samples were fixed in solution of formaldehyde, acetic acid, and 90\% ethanol (FAA 90); paradermal sections were cut according to Souza et al. (2012a), and cross sections of mesophyll and midrib were cut according to Souza et al. (2010).

Sections were photographed under an Olympus BX60 light optical microscope coupled to a digital camera. The parameter measured in the paradermal sections of the leaf was stomatal index (SI): [(number of stomata/ $\mathrm{mm}^{2}$ )/number of epidermal cells] $\left.\times 100\right]$. The parameters evaluated for the cross section of the midrib were as follows: xylem vessel diameter and area of perivascular fibers. For the leaf limb, the following parameters were measured: cuticle thickness of adaxial and abaxial surfaces. Evaluations in the leaf blade were performed $549 \mu \mathrm{m}(\mu \mathrm{m})$ away from the midrib. This distance was chosen based on the position of the secondary leaf ribs. For root anatomy, a root sample (with all regions) was collected, two plants/treatments/replications. Fixation and cross sections were performed according to Souza et al. (2009) and were photographed under an Olympus BX-60 light optical microscope, coupled to a digital 
camera. The following parameters were analyzed in the root: vascular cylinder area and cortex thickness. All these measurements were made by the image analysis program UTHSCSA ImageTool (University of Texas, San Antonio, USA) (Souza et al. 2009, 2010).

\section{6 $\mathrm{Cu}$ Content in Tissues and Indexes}

The dry matter of roots, stems, and leaves was ground in a Wiley mill and, with plant tissue samples, the determination of $\mathrm{Cu}$ contents by atomic absorption spectroscopy was performed, according to Carmo et al. (2000).

To evaluate the tolerance of $H$. courbaril plants and the ability to accumulate copper, tolerance index and translocation factor were calculated. The tolerance index (TI) is based on biomass production (Shi et al. 2011) and was used to evaluate the tolerance of this tree for each $\mathrm{Cu}$ concentration. The index was calculated as follows: $\mathrm{TI}=\mathrm{Bt} / \mathrm{Bc}$, where $\mathrm{Bt}$ (g/plant) is the biomass of plants cultivated in soils with $\mathrm{Cu}$ and $\mathrm{Bc}(\mathrm{g} / \mathrm{plant})$ is the biomass of control plants.

The translocation factor (TF) indicates the ability of the plant to translocate metals from the roots to the shoot, calculated as: $\mathrm{TF}=\mathrm{As} / \mathrm{Ar} \times 100$, where As $\left(\mathrm{mg} \mathrm{kg}^{-1}\right)$ is the total $\mathrm{Cu}$ accumulated in the shoot and $\mathrm{Ar}\left(\mathrm{mg} \mathrm{kg}^{-1}\right)$ is the total $\mathrm{Cu}$ accumulated in the roots (Shi et al. 2011).

\subsection{Data Analysis}

For all analyzed parameters, the means and \pm standard error (SE) were calculated. For the statistical analysis of

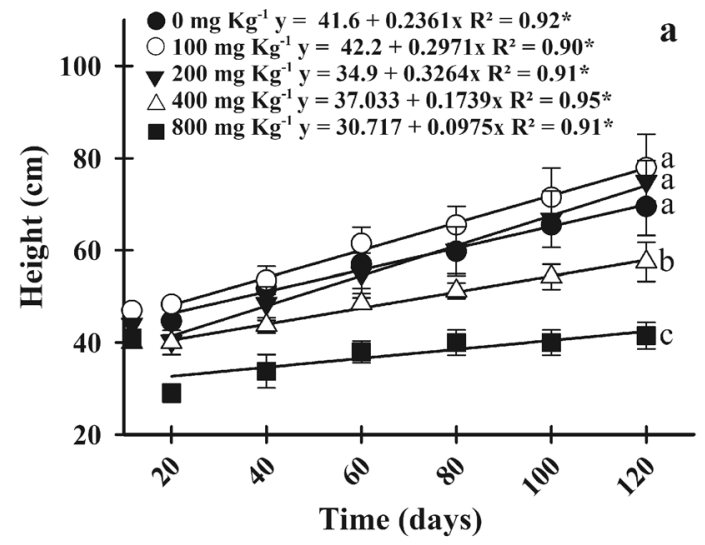

Fig. 1 Height and stem diameter of $H$. courbaril exposed to different $\mathrm{Cu}$ concentrations. Regressions with asterisk correspond to $p \leq 0.05 \%$ probability. Statistical difference by the Scott-Knott test at $5 \%$ probability between $\mathrm{Cu}$ concentrations at 120 days of the results, when significant, linear and non-linear regression analyses were used; the analysis of variance ANOVA and the Skott-Knott test were performed, using the software Sisvar version 4.3 (Universidade Federal de Lavras, Lavras, Brazil).

\section{Results and Discussion}

\subsection{Biometric Measurements}

In all treatments with copper $(\mathrm{Cu})$, the plants of $H$. courbaril maintained linear growth in height $(\mathrm{H})$ and stem diameter (SD) $(p<0.05)$ (Fig. 1a, b), with higher growth at concentrations of 0,100 , and $200 \mathrm{mg} \mathrm{kg}^{-1}$. However, at concentrations of 400 and $800 \mathrm{mg} \mathrm{kg}^{-1}$, it is observed that $\mathrm{Cu}$ negatively affected the height of the plants $(\mathrm{H})$, as well as stem diameter (SD) at the highest concentration $\left(800 \mathrm{mg} \mathrm{kg}^{-1}\right)$ $(p<0.05)$ (Fig. 1a, b).

Up to a concentration of $200 \mathrm{mg} \mathrm{kg}^{-1}$, copper favored growth, gas exchange and root morphology of H. courbaril plants, possibly due to the fact that it is a micronutrient, within the limits favorable to plant development (Souza et al. 2014). However, in excess in the soil, $\mathrm{Cu}$ induced a reduction in the growth of this tree due to its toxic potential at high concentrations, which results in the limitation of plant development (DalCorso et al. 2014; Adrees et al. 2015). This result resembles that found by Marco et al. (2016), who investigated excess $\mathrm{Cu}$ in tree species Senna multijuga and Erythrina cristagalli, and found a decrease in their growth,

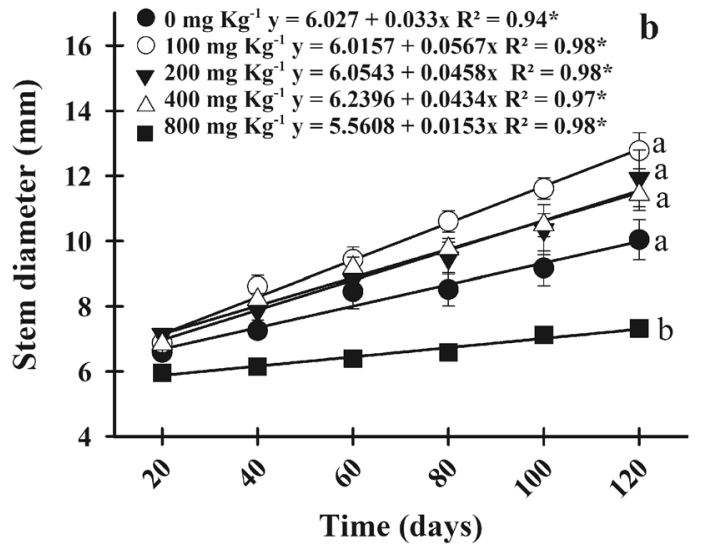

cultivation. Means followed by the same letter for treatments at 120 days of cultivation did not differ by the Skott-Knott test at 5\% probability $(p \leq 0.05)$. Each value indicates treatment means $\pm \mathrm{SE}$ 
probably due to excess $\mathrm{Cu}$, which reduces plant growth and stabilization in the subsequent stages of their development. The reduction in growth observed in plants exposed to the highest $\mathrm{Cu}$ concentrations can also be attributed to the reduction in carbon assimilation (Cambrollé et al. 2015).

\subsection{Effect of Copper on Gas Exchange}

At a concentration of $200 \mathrm{mg} \mathrm{kg}^{-1} \mathrm{Cu}, H$. courbaril plants showed higher photosynthesis $(A)$, stomatal conductance $\left(g_{\mathrm{s}}\right)$ and carboxylation efficiency $\left(A / C_{\mathrm{i}}\right)$, up to the period of 100 days, with a decline in the same parameters at 120 days (Fig. 2 a, b, d). However, it was observed that excess $\mathrm{Cu}$ in the soil $\left(800 \mathrm{mg} \mathrm{kg}^{-1}\right)$ caused a decrease in parameters $A, g_{\mathrm{s}}$ and $A / C_{\mathrm{i}}$ (Fig. 2a, b, d). $H$. courbaril showed an increase in water use efficiency $\left(A / g_{\mathrm{s}}\right)$ at a concentration of $800 \mathrm{mg} \mathrm{kg}^{-1} \mathrm{Cu}$ applied to the soil, with a decrease at 120 days (Fig. 2c).

In $H$. courbaril plants, the maximum net photosynthetic rate $\left(A_{\max }\right)$ was higher in the treatment with $200 \mathrm{mg} \mathrm{kg}^{-1}$, followed by the concentration of $100 \mathrm{mg} \mathrm{kg}^{-1} \mathrm{Cu}$, with an increase in the measurements performed over the days (Fig. 3a). At $800 \mathrm{mg} \mathrm{kg}^{-1} \mathrm{Cu}$ applied to the soil, the lowest $A_{\max }$ was observed (Fig. 3a).

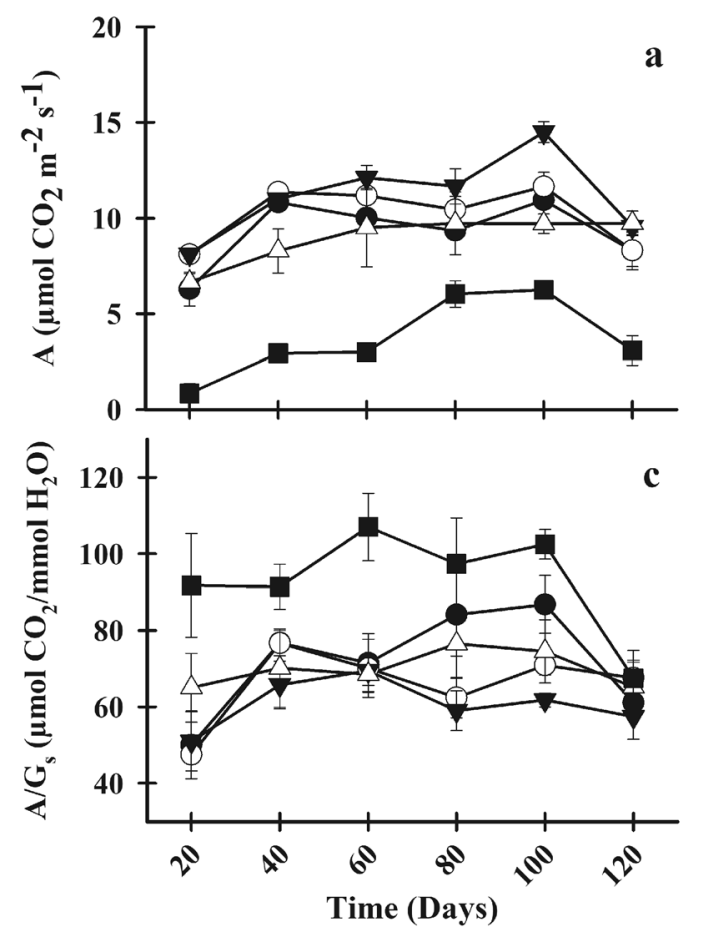

Regarding respiration rate in the dark $\left(R_{\mathrm{d}}\right)$, a greater $R_{\mathrm{d}}$ was observed at $100 \mathrm{mg} \mathrm{kg}^{-1}$, at 30 days of culture, followed by an apparent decline (Fig. 3b). At $800 \mathrm{mg} \mathrm{kg}^{-1}$, a smaller $R_{\mathrm{d}}$ occurred in relation to the other concentrations (Fig. $3 \mathrm{~b}$ ). $R_{\mathrm{d}}$ remained largely unchanged over time at this concentration. In the measurements, a lower light compensation point (LCP) was observed at a concentration of $800 \mathrm{mg} \mathrm{kg}^{-1}$ (Fig. 3c). After 6 days of cultivation, there was a significant increase and stabilization of this parameter for excess $\mathrm{Cu}$ (800 mg kg ${ }^{-1}$ ). On the other hand, for light saturation point (LSP), H. courbaril showed higher means at concentrations of 200 and $100 \mathrm{mg} \mathrm{kg}^{-1}$, and lower LSP at the highest $\mathrm{Cu}$ concentration $\left(800 \mathrm{mg} \mathrm{kg}^{-1}\right)$ (Fig. 3c). It is noticed that, over time, there was an increase in LSP at all concentrations, except for $0 \mathrm{mg} \mathrm{kg}^{-1}$. With respect to apparent quantum yield values $(\alpha)$ obtained for $H$. courbaril, it was observed that excess $\mathrm{Cu}$ $\left(800 \mathrm{mg} \mathrm{kg}^{-1}\right.$ ) caused a decrease and, with the increase in days of cultivation, an increase and stabilization in $\alpha$ was observed (Fig. 3d).

$\mathrm{Cu}$ acts as a structural element of mitochondria, chloroplasts, and proteins, such as plastocyanin, which is involved in the electron transport chain between PS II and PS I in the photochemical phase of photosynthesis

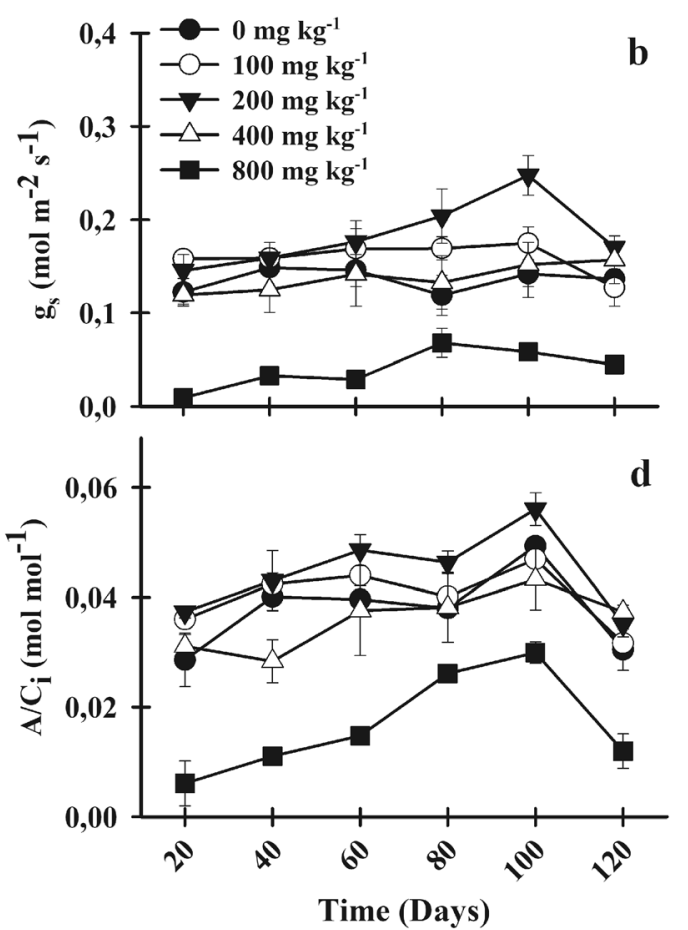

Fig. 2 Gas exchange of $H$. courbaril exposed to different $\mathrm{Cu}$ concentrations. a Photosynthesis $(A)$. b Stomatal conductance $\left(g_{\mathrm{s}}\right)$. $\mathbf{c}$ Water use efficiency $\left(A / g_{\mathrm{s}}\right)$. d Carboxylation efficiency $\left(A / C_{\mathrm{i}}\right)$. Each value indicates treatment means $\pm \mathrm{SE}$ 


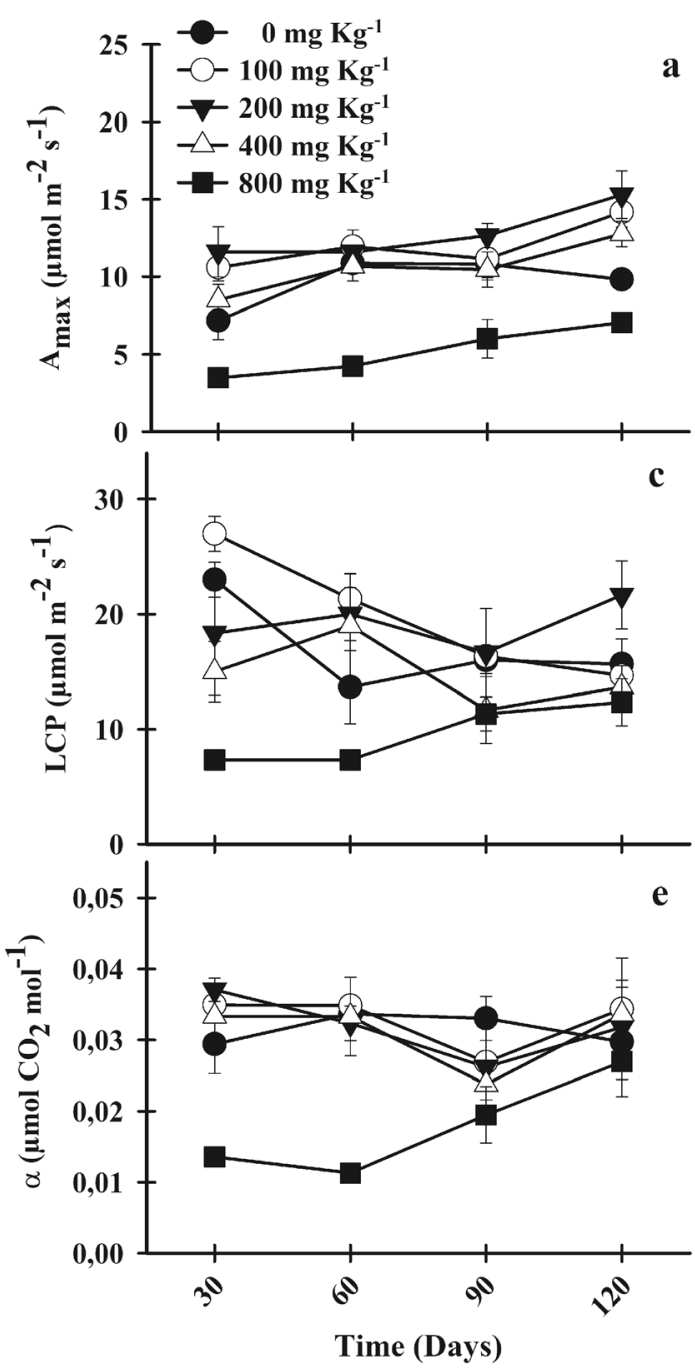

Fig. 3 a Maximum net photosynthetic rate $\left(A_{\max }\right)$. b Respiration rate in the dark (Rd). $\mathbf{c}$ Light compensation point (LCP). d Light saturation point (LSP). e Apparent quantum yield $(\alpha)$ in

(Yruela 2013; DalCorso et al. 2014; Adrees et al. 2015). The presence of copper in the soil at concentrations up to $200 \mathrm{mg} \mathrm{kg}^{-1}$ positively influenced the evaluated parameters, resulting in a higher photosynthesis $(A)$ in H. courbaril plants. Another probable factor for the high $A$ is the high stomatal conductance $\left(g_{\mathrm{s}}\right)$ at this concentration, thus favoring greater $\mathrm{CO}_{2}$ fixation by these plants.

Excess $\mathrm{Cu}$ ions in plants can cause competition with other metallic ions $(\mathrm{Zn}, \mathrm{Fe}, \mathrm{Ni})$ and substitution of structural elements in enzymes, such as ribulose-1,5bisphosphate carboxylase/oxygenase (RuBisco), causing a disturbance in photosynthesis; leading to an increase in intracellular reactive oxygen species (ROS) in

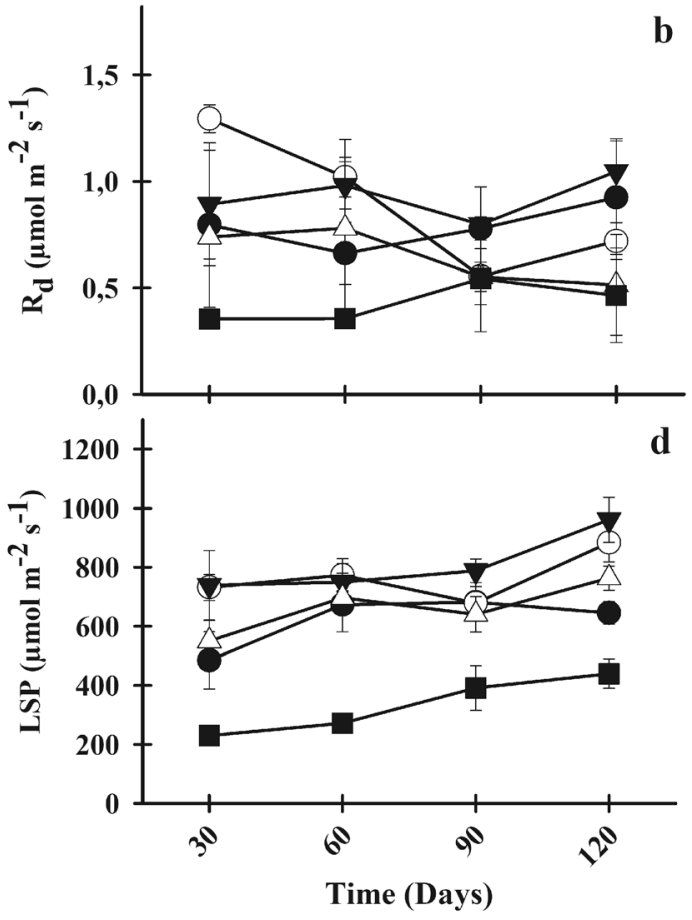

H. courbaril plants exposed to different $\mathrm{Cu}$ concentrations. Each value indicates treatment means $\pm \mathrm{SE}$

leaves that are highly toxic and increasing lipid peroxidation; decreasing carbon fixation and energy production and, consequently, reducing or inhibiting plant development (Küpper and Andresen 2016). This possibly explains the lower photosynthesis $(A)$ and the low maximum net photosynthetic rate $\left(A_{\max }\right)$ found in $H$. courbaril plants at the highest concentration $\left(800 \mathrm{mg} \mathrm{kg}^{-1}\right)$. Another likely explanation for the results found for $A$ and $A_{\max }$ could be attributed to the different effects of $\mathrm{Cu}$ toxicity on the integrity or function of the photochemical apparatus - biochemical limitation, as well as its impact on leaf chlorophyll concentrations (Cambrollé et al. 2015). Fluorescence may occur, and it is another limitation for $\mathrm{A}$, suggesting that excess $\mathrm{Cu}$ 
increases photoinhibition induced by light stress (Zhang et al. 2013; Cambrollé et al. 2015). These deleterious effects of excess $\mathrm{Cu}$ on this tree can be confirmed when analyzing carboxylation efficiency $\left(A / C_{\mathrm{i}}\right)$, which is reduced at a concentration of $800 \mathrm{mg} \mathrm{kg}^{-1}$, possibly due to toxicity that led to the inhibition of carboxylic enzymes (rubisco) (Mateos-Naranjo et al. 2013).

The maximum net photosynthetic rate $\left(A_{\max }\right)$ reflects the maximum photosynthetic capacity of the leaf (Zhang et al. 2014). $A_{\max }$ was influenced by the high $\mathrm{Cu}$ concentration $\left(800 \mathrm{mg} \mathrm{kg}^{-1}\right)$, indicating that the photosynthetic capacity of $H$. courbaril plants decreased with excess $\mathrm{Cu}$. This fact can be reinforced by the light compensation point (LCP) and light saturation point (LSP), which reflect the plant ability to use the lowest and highest levels of light, respectively, showing the relationship between light and photosynthesis (Zhang et al. 2014), which was limited at $800 \mathrm{mg} \mathrm{kg}^{-1}$, when compared to the other treatments. These results differ from those found by Zhang et al. (2014), where LCP and LSP were higher with excess heavy metal, indicating that the metal could increase light use efficiency at high light levels and reduce it at low light levels. LCP is the light value in which $\mathrm{CO}_{2}$ fixation rate in photosynthesis is equal to the rate of $\mathrm{CO}_{2}$ release in respiration and photorespiration (Nunes et al. 2009). The high LCP reflects a higher respiration, a lower Rubisco carboxylase activity, and a greater Rubisco oxygenase activity, suggesting a possible protection mechanism to avoid photoinhibition, dissipating the excess of ATP and $\mathrm{NADPH}$, producing internal $\mathrm{CO}_{2}$ (maintenance of Rubisco activity) and consuming oxidants $\left(\mathrm{H}_{2} \mathrm{O}_{2}\right)$ through catalysis (Baccio et al. 2009). $\mathrm{Cu}$ is possibly at a very toxic level in the soil, reflecting a large amount of intracellular ions, preventing this protection mechanism with the increase in LCP. Respiration rate in the dark $\left(R_{\mathrm{d}}\right)$ was lower at $800 \mathrm{mg} \mathrm{kg}^{-1}$, when compared to the other treatments, possibly due to $\mathrm{Cu}$ toxicity. In apparent quantum yield $(\alpha)$, the negative effect of $\mathrm{Cu}$ excess is observed; however, over time (days), $H$. courbaril plants adapt to the stress condition induced by this metal, increasing $\alpha$ and showing tolerance.

The higher water use efficiency $\left(A / g_{\mathrm{s}}\right)$ in $H$. courbaril plants at the highest copper concentration reflects in water savings. Plants that save water in environments with excess heavy metals are important for phytoremediation programs, once they are not damaged by additional stresses such as water, suggesting the possible use of this species in phytoremediation programs, since it tolerates more environmental variations such as drought. This fact favors a better performance (survival) of the plant, since $A / g_{\mathrm{s}}$ is an indicator parameter of drought tolerance (Pinheiro et al. 2014). One of the major hurdles of phytoremediation is the influence of other environmental stresses (besides the presence of metal) on contaminant uptake by plants (Ali et al. 2013).

\subsection{Root System Morphology and Dry Matter Attributes}

Excess $\mathrm{Cu}$ negatively affected all studied parameters of root system morphology, with a marked decline at $800 \mathrm{mg} \mathrm{kg}^{-1} \mathrm{Cu}$ for length, surface area, mean diameter, and root volume of $H$. courbaril plants (Fig. 4a-d). However, it was observed that, for root length parameters up to a concentration of $172.68 \mathrm{mg} \mathrm{kg}^{-1}$, surface area of $169.37 \mathrm{mg} \mathrm{kg}^{-1}$, mean root diameter of $166.66 \mathrm{mg} \mathrm{kg}^{-1}$, and root volume of $193.16 \mathrm{mg} \mathrm{kg}^{-1}$, root development is favored and, above these concentrations, toxic and inhibitory effects are observed in the root system (Fig. 4a-d).

Regarding the distribution of length, surface area, and volume through diameter classes for $H$. courbaril plants, the same behavior of the previous parameters was observed (Figs. 4 and 5), with root growth at initial concentrations above the control $\left(0 \mathrm{mg} \mathrm{kg}^{-1}\right)$ and root growth inhibition at higher copper concentrations. In general, the root system in $H$. courbaril is dominated by fine roots. However, it was observed that concentrations of 100, 200, and $400 \mathrm{mg} \mathrm{kg}^{-1} \mathrm{Cu}$ have higher length, surface area, and volume of finer roots $(0$ to $1 \mathrm{~mm})$, when compared to the control $\left(0 \mathrm{mg} \mathrm{kg}^{-1}\right)$. It is worth mentioning that, despite leading to an increase in these characteristics for fine roots at concentrations of 200 and $400 \mathrm{mg} \mathrm{kg}^{-1} \mathrm{Cu}$, an increase in medium roots (with a diameter of $2 \mathrm{~mm}$ ) is simultaneously observed. At $800 \mathrm{mg} \mathrm{kg}^{-1}$, a decrease in length, surface area, and volume of finer roots is observed (Fig. 5a-c).

For shoot dry matter (SDM), up to a concentration of $100 \mathrm{mg} \mathrm{kg}^{-1}$ and root dry matter (RDM) up to $200 \mathrm{mg} \mathrm{kg}^{-1}$, an increase in biomass occurs, followed by a decrease for these parameters at the other concentrations (Fig. 6a, b). The ratio between RDM/SDM increases at higher concentrations (Fig. 6c). For specific root length (SRL), the highest values were observed in the control and at $100 \mathrm{mg} \mathrm{kg}^{-1}$, with a decrease at 200 , 400 and $800 \mathrm{mg} \mathrm{kg}^{-1}$ (Fig. 6d). Up to $200 \mathrm{mg} \mathrm{kg}^{-1}$, root fineness (RF) is favored, followed by a decrease at 400 

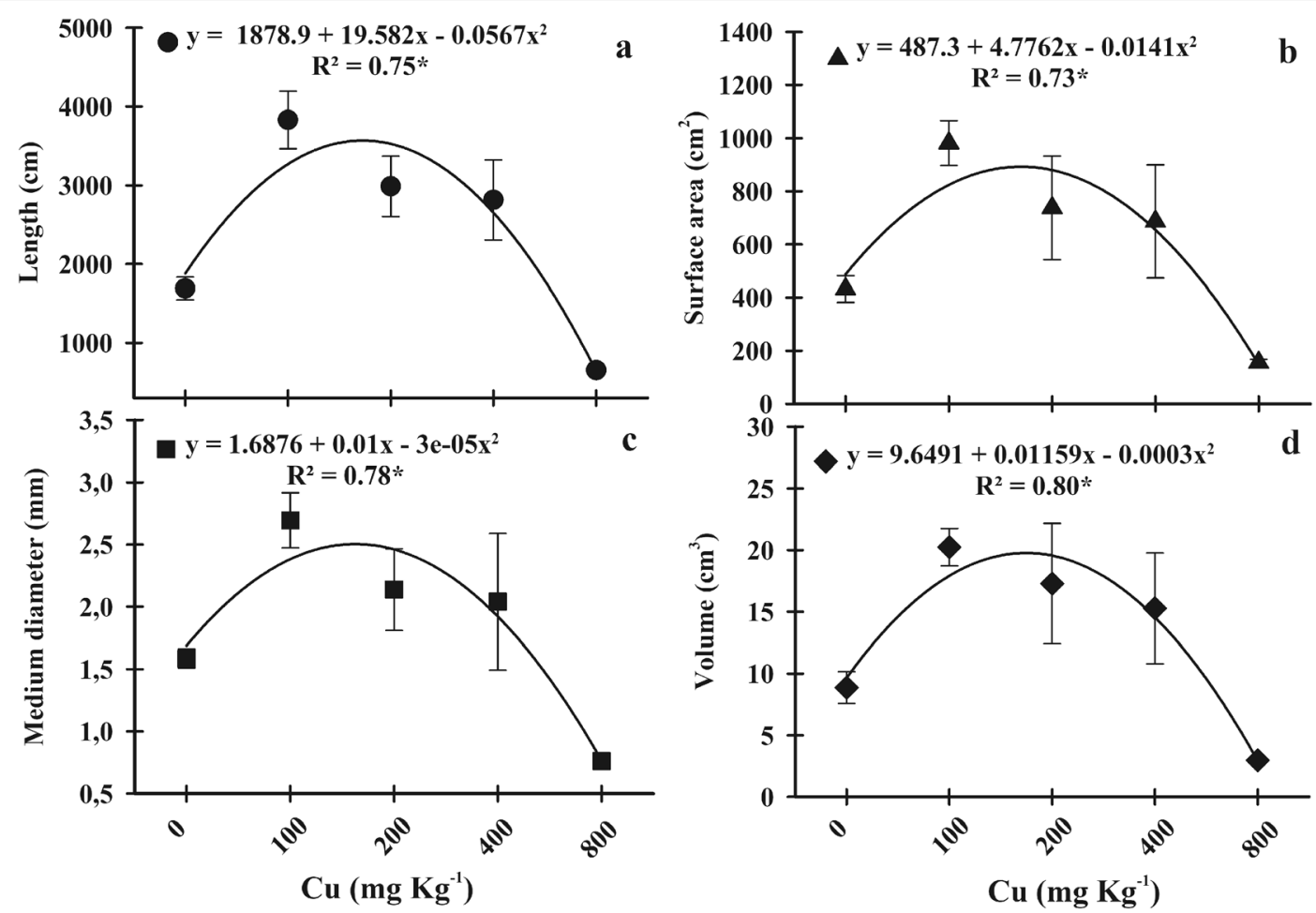

Fig. 4 Root characteristics. a Length, $\mathbf{b}$ surface area, $\mathbf{c}$ mean diameter, and $\mathbf{d}$ volume of the species $H$. courbaril exposed to different $\mathrm{Cu}$ concentrations. $* p \leq 0.05 \%$

and $800 \mathrm{mg} \mathrm{kg}^{-1}$, due to the toxic effect of $\mathrm{Cu}$ (Fig. 6e). Root tissue density (RMDe) showed an increase with high $\mathrm{Cu}$ concentrations applied to the soil (Fig. 6f).

The morphological parameters of roots can be influenced by biotic and abiotic factors such as heavy metals, which may determine plant survival in a given environment (Cai et al. 2014). A well-developed root system is an important characteristic for stress tolerance. In general, exposure to stress leads to remodeling in root morphology (Cai et al. 2014). High copper concentrations affected root morphology/architecture in $H$. courbaril. The toxic effect of $\mathrm{Cu}$ resulted in a decrease in length, surface area, mean diameter, and root volume, which reflected in a reduction in both root and shoot biomass at these concentrations. Batool et al. (2015) emphasize that the evident reduction in root growth may be due to a reduction in cell division, leading to an increase in the cell wall thickness of the roots, when exposed to heavy metals.

These results were similar to those found by Cai et al. (2014) in the root morphology analysis of Elsholtzia haichowensis, emphasizing that the sharp reduction in root volume under $\mathrm{Cu}$ stress reflects the relevant decrease in root biomass, which depends directly on cell division and stretching. Similar effects were found by
Bochicchio et al. (2015) in a combination of heavy metals $\mathrm{Cd}, \mathrm{Cu}$ and $\mathrm{Zn}$ on the root morphology of Arabidopsis thaliana. Marco et al. (2016) reported that increased $\mathrm{Cu}$ reduced morphological parameters in the studied trees (Senna multijuga and Erythrina crista-galli). Feigl et al. (2013) found the inhibitory effect on the most prominent root system in Brassica juncea, compared to Brassica napus, caused by $\mathrm{Cu}$ stress, showing genetic variability among the species in the tolerance to this metal.

On the other hand, under micronutrient conditions, $\mathrm{Cu}$ favored the root development of $H$. courbaril and, according to Imada et al. (2008), the root surface area is the one that is most related to nutrient absorption, and an increase in root volume leads to a greater efficiency in nutrient absorption, favoring a good plant development.

$\mathrm{Cu}$ favored root length development, surface area, and volume of fine roots, which are the roots suitable for water absorption, up to a concentration of $400 \mathrm{mg} \mathrm{kg}^{-1}$. However, even at $400 \mathrm{mg} \mathrm{kg}^{-1}$, it was observed that the favoring of roots classified as thick $(\varnothing>2.0 \mathrm{~mm})$ (Magalhães et al. 2012) also occurred as a sign of support, not absorption roots. Thus, up to $200 \mathrm{mg} \mathrm{kg}^{-1}$, concentration seems to have actually favored the root system of H. courbaril in soil exploration. However, toxic and 


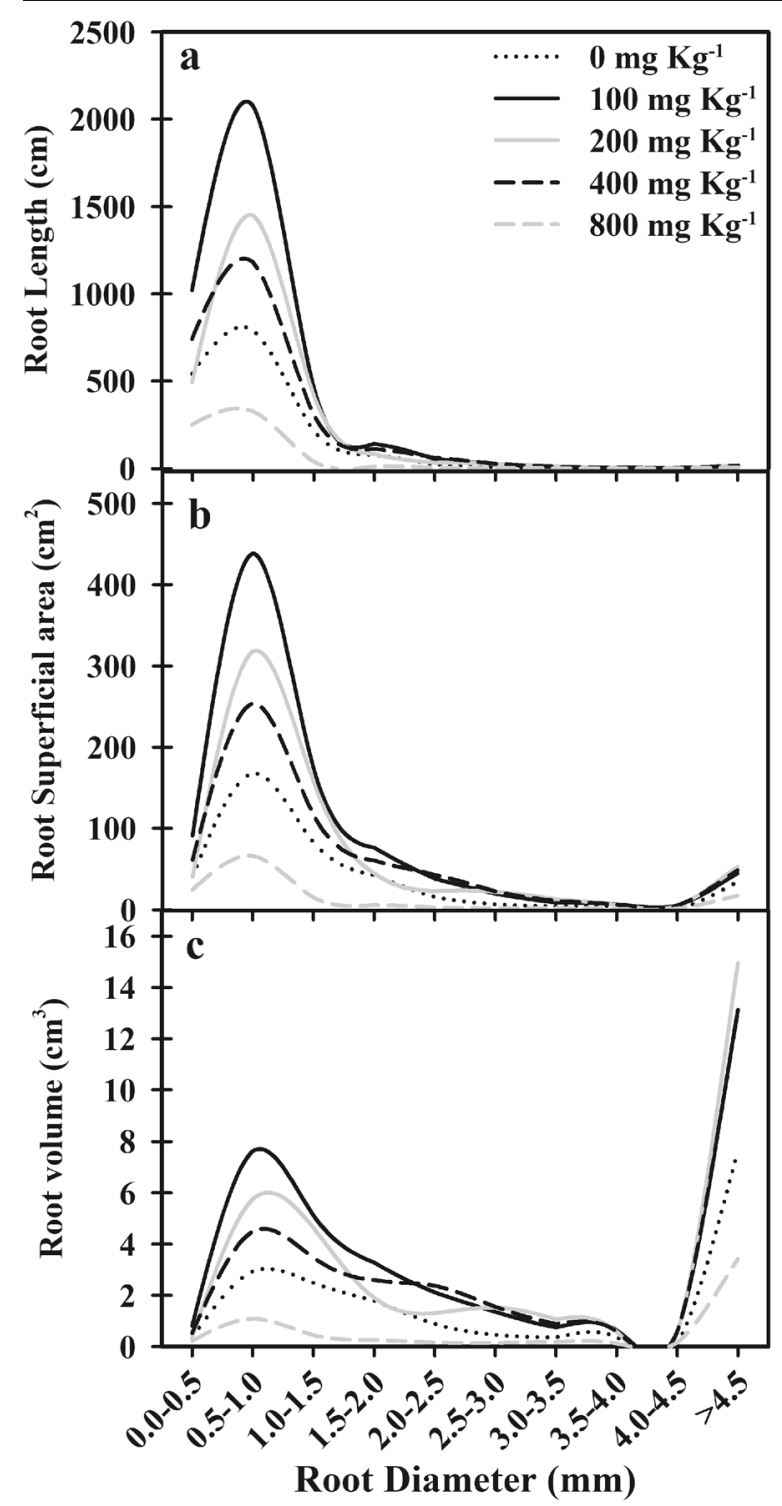

Fig. 5 a Root length, b root surface area, and c root volume distributed through diameter classes in $H$. courbaril exposed to different $\mathrm{Cu}$ concentrations

inhibitory effects are observed for the same parameters, when at high concentrations in the soil, since fine roots are more sensitive under high $\mathrm{Cu}$ levels. In addition to the decrease in primary and lateral roots, root number and density are also reduced by $\mathrm{Cu}$ (Feigl et al. 2013). This fact can be observed when analyzing root anatomy, where the plants of this tree presented smaller cortex thickness and vascular cylinder area.

The application of the highest $\mathrm{Cu}$ concentration in the soil caused a decrease in dry matter attributes, with an increase in the ratio root/shoot dry matter (RDM/SDM), suggesting that there is an increase in root tissue density in this tree at the highest concentrations. It is known that a greater specific root length (SRL) reflects in a greater exploration and acquisition of water and nutrients in the soil per carbon unit (Bouma et al. 2001). This fact corroborates the result found for root fineness (RF). At $100 \mathrm{mg} \mathrm{kg}^{-1}$, SRL is favored, which was also observed with the increase in fine roots (RF). In reforestation areas, this $\mathrm{Cu}$ concentration could be indicated due to the stimulus in root increase for soil exploration.

The high root tissue density (RMDe) (roots with large amounts of dead and fibrous matter) is an example of the characteristic of species inserted in stress environments, which eventually reduce specific root length (Wahl and Ryser 2000). Cu can increase lignification in tolerant species, since it accumulates in the cell wall (Colzi et al. 2015) and may also be adhered to apoplastic barriers in the exodermis and endodermis (Caspary striae) (Freitas et al. 2015). This fact possibly explains the increase in the area of perivascular fibers (lignin) in $H$. courbaril leaves. $\mathrm{Cu}$ can also increase lignification in xylem cell walls (Lequeux et al. 2010), which is probably related to the increase in xylem diameter, that is, larger caliber vessels have a higher amount of lignin. Fibers are important in plants that are inserted in environments with metals, since lignin has adsorption sites of heavy metals (Lin et al. 2005). Fu et al. (2015) reported that the increase in $\mathrm{Cu}$ provided an increase in xylem vessels by $60 \%$ in E. haichowensis, which corroborates the increase in xylem vessels in the leaves of the studied tree.

\subsection{Leaf and Root Anatomy}

In $H$. courbaril leaves, it is observed that excess $\mathrm{Cu}$ caused a decrease in stomatal density, adaxial and abaxial cuticle thickness, and area of perivascular fibers, except for xylem diameter (Fig. 7a-e). On the other hand, for the root anatomy of these plants, there is a reduction in vascular cylinder area and in cortex thickness, with the increase in $\mathrm{Cu}$ concentrations in the soil (Fig. 7f, g).

The absorption of heavy metals by a plant can cause several anatomical changes, with possible functional consequences in the plant, besides other morphophysiological alterations (Batool et al. 2015). The abaxial cuticle in the leaves, as well as the vascular cylinder area and cortex thickness in $H$. courbaril roots, was affected by excess $\mathrm{Cu}$. These anatomical changes in leaves and roots 

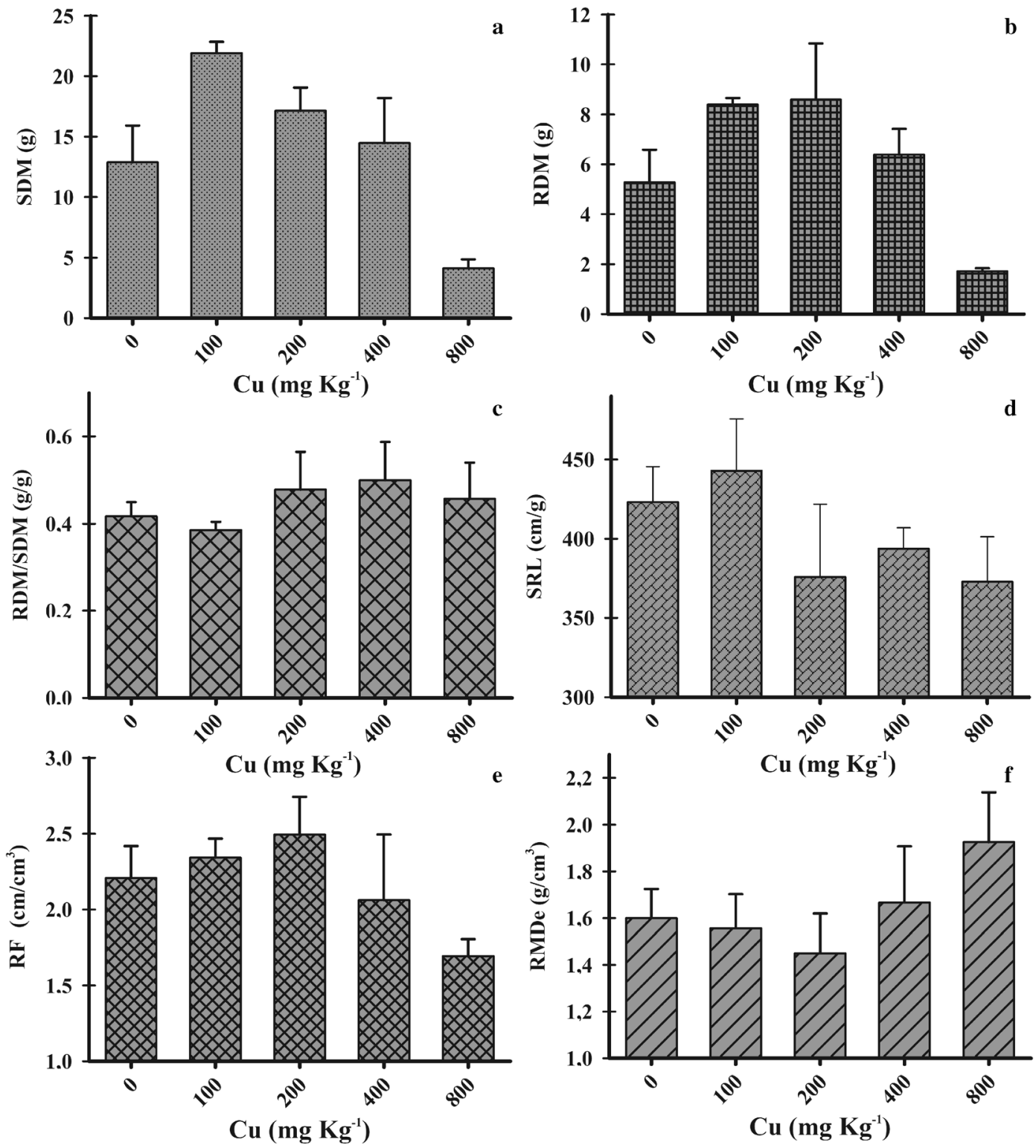

Fig. 6 Dry matter attributes and morphology of $H$. courbaril plants exposed to different $\mathrm{Cu}$ concentrations. a Shoot dry matter (SDM). b Root dry matter (RDM). c Ratio between root dry matter

possibly influenced the negative effect on gas exchange and, mainly, the root morphology of this tree. However, up to $200 \mathrm{mg} \mathrm{kg}^{-1}, \mathrm{Cu}$ stimulates cuticle production in the leaves, which would possibly help these plants survive under stress conditions, such as drought due to decreased transpiration. This result resembles those found by Fu et al. (2015).

The stomatal density of $H$. courbaril plants was favored up to $200 \mathrm{mg} \mathrm{kg}^{-1} \mathrm{Cu}$, which explains the higher photosynthetic rate $\left(A\right.$ and $A_{\max }$ ). Even with

and shoot dry matter (RDM/SDM). d Specific root length (SRL). e Root fineness (RF). f Root tissue density (RMDe). Each value indicates treatment means $\pm \mathrm{SE}$

a decline in stomatal density at the highest concentrations, it was still similar to the control $\left(0 \mathrm{mg} \mathrm{kg}{ }^{-1}\right)$, differing from the results found by Silva et al. (2012), who reported a decreasing trend for stomatal density at the highest concentrations. The same authors further emphasize that a reduction in stomatal size can occur and may lead to negative impacts on gas exchange, such as photosynthesis and transpiration, due to the presence of the metal, inducing stomatal closure. 


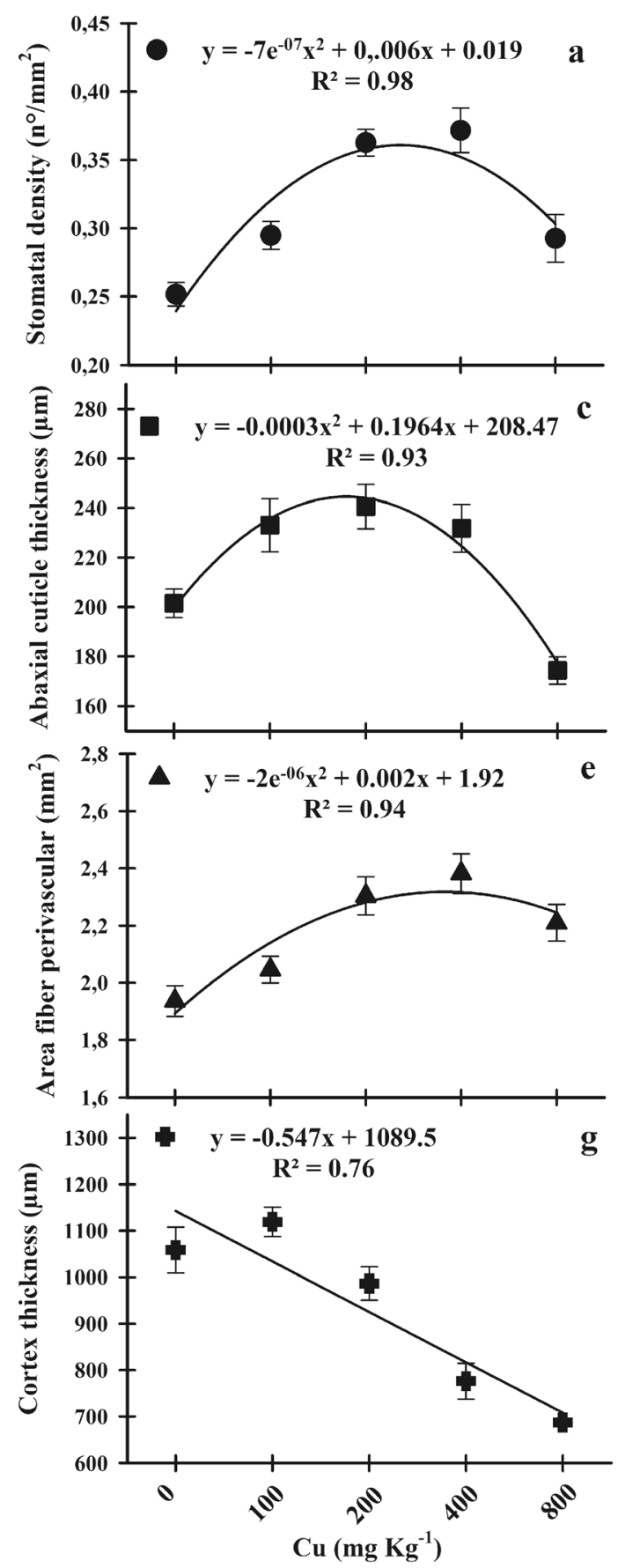

Fig. 7 Leaf and root anatomy of $H$. courbaril plants exposed to increasing $\mathrm{Cu}$ concentrations. Leaf: a stomatal density, b adaxial cuticle thickness, $\mathbf{c}$ abaxial cuticle thickness, $\mathbf{d}$ xylem diameter, $\mathbf{e}$

When exposed to increasing $\mathrm{Cu}$ concentrations, the smallest vascular cylinder area and cortex thickness of $H$. courbaril plants may be related to the marked decrease in the size of root tissue cells, due

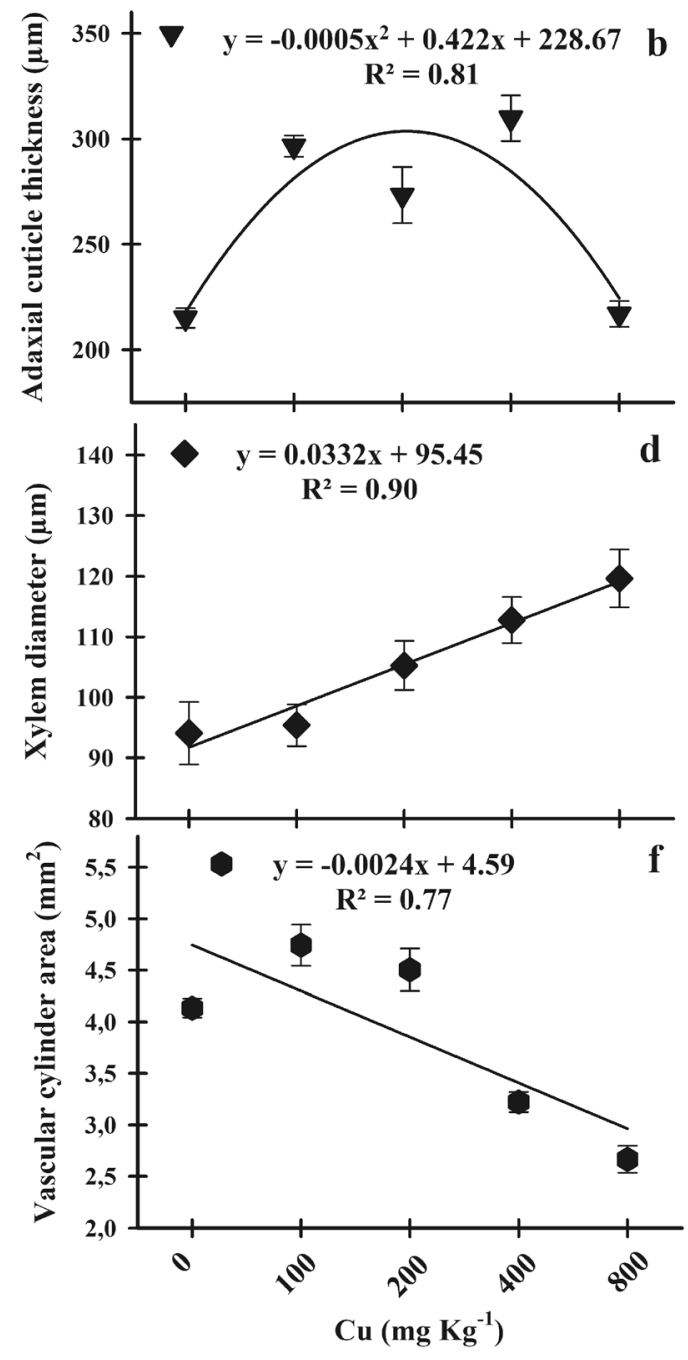

area of perivascular fibers. Root: $\mathbf{f}$ Vascular cylinder area and $\mathbf{g}$ cortex thickness. Regressions with asterisk correspond to $p \leq$ $0.05 \%$ probability. Each value indicates treatment means $\pm \mathrm{SE}$

to the decreased elasticity of the cell walls, either of the cortical parenchyma or the conduction system (xylem and phloem), resulting in reduced root diameter, when exposed to excess metals (Batool et al. 
2015). This fact may also be related to high $\mathrm{Cu}$ levels, altering the photosynthetic metabolism of leaves, responsible for the energy supply (ATP and $\mathrm{NADPH}$ ) for root development, which reflects in morphological changes in the root system.

\subsection{Copper Content in Tissues and Indexes}

With the increase in copper in the soil, its increase was also observed in H. courbaril tissues $(p<0.05)$ (Fig. 8). $\mathrm{Cu}$ was absorbed and mainly allocated to the roots of this species (Fig. 8).

Metal absorption by plants depends on the physiological requirement and metal availability in the soil (DalCorso et al. 2014). Copper is absorbed and found at higher concentrations in roots, since it strongly binds to the cell wall of root cells and, therefore, it is not easily mobile in the plant, resulting in a low translocation of this metal to the shoot (Kabata-Pendias 2011). The $\mathrm{Cu}$ absorbed by H. courbaril plants was retained in the roots, mainly at the highest concentrations. This result resembles that found by Silva et al. (2015), with emphasis on the tree Enterolobium contortisiliquum (Vell.) Morong.; it is the main species studied for accumulating $\mathrm{Cu}$ in the root system. This behavior is used by many plants as a tolerance mechanism to heavy metals to reduce metal translocation to the shoot and thus avoid damage caused by the toxicity of the heavy metal to the photosynthetic apparatus present in the leaves (Marco et al. 2016). This fact corroborates the results found in this study, once they did not die and still accumulated the metal in the roots, although the plants suffered with the presence of excess copper.

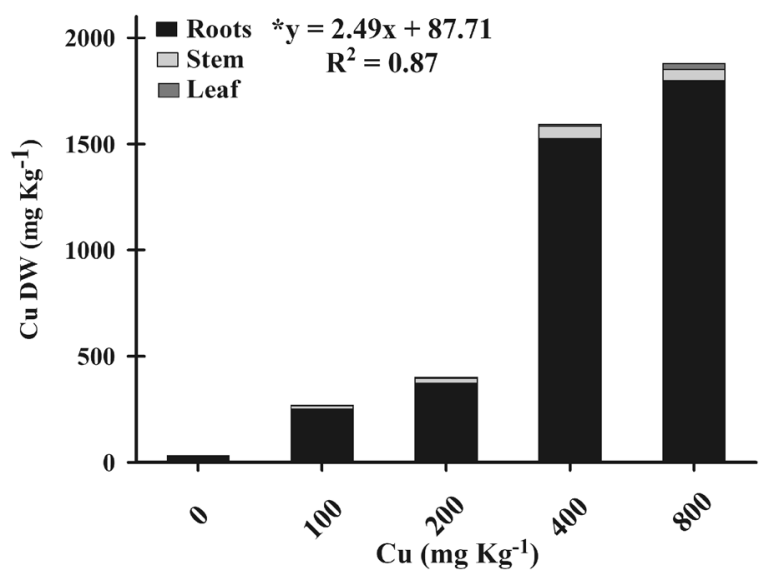

Fig. 8 Copper content in roots, stems, and leaves of $H$. courbaril plants exposed to different $\mathrm{Cu}$ concentrations. Total $\mathrm{Cu}$ bioaccumulated in plants $p \leq 0.05 \%$ (asterisk)
Table 2 Tolerance index (TI) and translocation factor (TF) of H. courbaril plants exposed to different $\mathrm{Cu}$ concentrations. Each value indicates treatment means $\pm \mathrm{SE}$. Means followed by the same letter do not differ by the Skott-Knott test at $5 \%$ probability $(p \leq 0.05)$

\begin{tabular}{lll}
\hline $\mathrm{Cu}\left(\mathrm{mg} \mathrm{kg}^{-1}\right)$ & TI & TF \\
\hline 100 & $1.67 \pm 0.11 \mathrm{a}$ & $6.46 \pm 0.66 \mathrm{a}$ \\
200 & $1.42 \pm 0.45 \mathrm{a}$ & $7.73 \pm 0.95 \mathrm{a}$ \\
400 & $1.16 \pm 0.52 \mathrm{a}$ & $4.35 \pm 0.28 \mathrm{~b}$ \\
800 & $0.32 \pm 0.08 \mathrm{~b}$ & $4.45 \pm 0.72 \mathrm{~b}$ \\
\hline
\end{tabular}

For tolerance index (TI) and translocation factor (TF) in $H$. courbaril plants, it is observed that the values decreased with increasing $\mathrm{Cu}$ concentrations applied to the soil $(p<0.05)$ (Table 2).

Even with the toxic effect of $\mathrm{Cu}$ at high concentrations, $H$. courbaril plants presented tolerance and survival. The tolerance index (TI) confirms this fact, based on biomass production, even at the highest concentration, where this tree managed to survive. TI results close to 1.0 indicate higher stress tolerance caused by the metal (Souza et al. 2012b). Increasing $\mathrm{Cu}$ concentrations incorporated in the soil reduced the translocation factor (TF) of this tree, and it was observed that only $4.45 \% \mathrm{Cu}$ was translocated from the roots to the shoot by the plants when they were exposed to the concentration of $800 \mathrm{mg} \mathrm{kg}^{-1}$. Cu concentrations higher in the roots and lower in the shoot suggest that there may be some protection mechanisms through which $\mathrm{Cu}$ translocation from shoot to root was limited (Wang et al. 2016). This fact is probably related to tolerance mechanisms against the deleterious effects that excess $\mathrm{Cu}$ can cause in the plant (Cambrollé et al. 2013). A study by Marco et al. (2016) with trees showed similar results with TF reduction in soils with $\mathrm{Cu}$ in Senna multijuga and Erythrina crista-galli.

\section{Conclusion}

Up to a concentration of $200 \mathrm{mg} \mathrm{kg}^{-1}$, copper favored and stimulated growth, gas exchange and root morphoanatomy of $H$. courbaril plants. However, excess $\mathrm{Cu}\left(800 \mathrm{mg} \mathrm{kg}^{-1}\right)$ caused toxicity, with a decrease in photosynthesis and biochemical limitations, inhibition of root development, mainly of fine roots, and changes in leaf and root anatomy 
for this tree. $\mathrm{Cu}$ was accumulated in the roots of these plants as a protection mechanism to the photosynthetic apparatus present in the leaves. Plants of Hymenaea courbaril L. showed high tolerance to excess copper and can be indicated for areas contaminated by this metal and phytoremediation programs such as phytostabilization.

Acknowledgements This paper is dedicated to Prof. Dr. Marcelo Polo, Federal University of Alfenas, Alfenas, MG, Brazil, for the long-term merits of his studies on plant ecophysiology.

\section{References}

Adrees, M., Ali, S., Rizwan, M., Ibrahim, M., Abbas, F., Farid, M., Zia-ur-Rehman, M., Irshad, M. K., \& Bharwana, S. A. (2015). The effect of excess copper on growth and physiology of important food crops: a review. Environmental Science and Pollution Research, 22(11), 8148-8162.

Ali, H., Khan, E., \& Sajad, M. A. (2013). Phytoremediation of heavy metals - concepts and applications. Chemosphere, 91(7), 869-881.

Baccio, D., Tognetti, R., Minnocci, A., \& Sebastiani, L. (2009). Responses of the Populus $x$ euramericana clone I-214 to excess zinc: carbon assimilation, structural modifications, metal distribution and cellular localization. Environmental and Experimental Botany, 67(1), 153-163.

Batool, R., Hameed, M., Ashraf, M., Ahmad, M. S. A., \& Fatima, S. (2015). Physio-anatomical responses of plants to heavy metals. In: M. Öztürk, M. Ashraf, A. Aksoy, M.S.A. Ahmad (Eds.) Phytoremediation for green energy (pp. 79-96). Netherlands: Springer.

Bochicchio, R., Sofo, A., Terzano, R., Gattullo, C. E., Amato, M., \& Scopa, A. (2015). Root architecture and morphometric analysis of Arabidopsis thaliana grown in $\mathrm{Cd} / \mathrm{Cu} / \mathrm{Zn}$-gradient agar dishes: a new screening technique for studying plant response to metals. Plant Physiology and Biochemistry, 91, 20-27.

Bouma, T. J., Nielsen, K. L., Van Hal, J., \& Koutstaal, B. (2001). Root system topology and diameter distribution of species from habitats differing in inundation frequency. Functional Ecology, 15(3), 360-369.

Cai, S., Xiong, Z., Li, L., Li, M., Zhang, L., Liu, C., \& Xu, Z. (2014). Differential responses of root growth, acid invertase activity and transcript level to copper stress in two contrasting populations of Elsholtzia haichowensis. Ecotoxicology, 23(1), 76-91.

Cambrollé, J., Mancilla-Leytón, J. M., Muñoz-Vallés, S., Figueroa-Luque, E., Luque, T., \& Figueroa, M. E. (2013). Effects of copper sulfate on growth and physiological responses of Limoniastrum monopetalum. Environmental Science and Pollution Research, 20(12), 8839-8847.

Cambrollé, J., García, J. L., Figueroa, M. E., \& Cantos, M. (2015). Evaluating wild grapevine tolerance to copper toxicity. Chemosphere, 120, 171-178.

Carmo, C. A. F. S., Araújo, W. S., Bernardi, A. C. C. \& Saldanha, M. F. C. (2000) Métodos de análise de tecidos vegetais utilizados na Embrapa Solos. Embrapa Solos, Rio de Janeiro. http://www. infoteca.cnptia.embrapa.br/bitstream/doc/337672 /1/Metododeanalisedetecido.pdf. (in portuguese).

Colzi, I., Pignattelli, S., Giorni, E., Papini, A., \& Gonnelli, C. (2015). Linking root traits to copper exclusion mechanisms in Silene paradoxa L.(Caryophyllaceae). Plant and Soil, 390(1-2), 1-15.

DalCorso, G., Manara, A., Piasentin, S., \& Furini, A. (2014). Nutrient metal elements in plants. Metallomics, 6(10), 1770-1788.

Ent, A. V. D., Baker, A. J., Reeves, R. D., Pollard, A. J., \& Schat, H. (2013). Hyperaccumulators of metal and metalloid trace elements: facts and fiction. Plant and Soil, 362(1-2), 319334.

Feigl, G., Kumar, D., Lehotai, N., Tugyi, N., Molnár, Á., Ördög, A., Szepesi, Á., Gémes, K., Laskay, G., Erdei, L., \& Kolbert, Z. (2013). Physiological and morphological responses of the root system of Indian mustard (Brassica juncea L. Czern.) and rapeseed (Brassica napus L.) to copper stress. Ecotoxicology and Environmental Safety, 94, 179-189.

Freitas, T. A., França, M. G. C., de Almeida, A. A. F., de Oliveira, S. J. R., de Jesus, R. M., Souza, V. L., Silva, J. V. S., \& Mangabeira, P. A. (2015). Morphology, ultrastructure and mineral uptake is affected by copper toxicity in young plants of Inga subnuda subs. luschnathiana (Benth.) TD Penn. Environmental Science and Pollution Research, 22(20), 15479-15494.

Fu, L., Chen, C., Wang, B., Zhou, X., Li, S., Guo, P., Shen, Z., Wang, G., \& Chen, Y. (2015). Differences in copper absorption and accumulation between copper-exclusion and copperenrichment plants: a comparison of structure and physiological responses. PLoS One, 10(7), e0133424.

Gautam, S., Anjani, K., \& Srivastava, N. (2016). In vitro evaluation of excess copper affecting seedlings and their biochemical characteristics in Carthamus tinctorius L. (variety PBNS-12). Physiology and Molecular Biology of Plants, 22(1), 121-129.

Imada, S., Yamanaka, N., \& Tamai, S. (2008). Water table depth affects Populus alba fine root growth and whole plant biomass. Functional Ecology, 22(6), 1018-1026.

Kabata-Pendias, A. (2011). Trace elements in soils and plants (4th ed.). London: CRC Press.

Küpper, H., \& Andresen, E. (2016). Mechanisms of metal toxicity in plants. Metallomics, 8, 269-285.

Lequeux, H., Hermans, C., Lutts, S., \& Verbruggen, N. (2010). Response to copper excess in Arabidopsis thaliana: impact on the root system architecture, hormone distribution, lignin accumulation and mineral profile. Plant Physiology and Biochemistry, 48(8), 673-682.

Lin, C. C., Chen, L. M., \& Liu, Z. H. (2005). Rapid effect of copper on lignin biosynthesis in soybean roots. Plant Science, 168(3), 855-861.

Magalhães, P. C., De Souza, T. C., Cantão, F. R. D. O., \& Padilha, F. A. (2012). Root morphology of maize lines with contrasting drought resistance under three toxic levels of aluminum. Brazilian Journal of Maize and Sorghum, 11(1), 35-48.

Marco, R., Silva, R. F., Andreazza, R., Ros, C. O., Scheid, D. L., \& Bertollo, G. M. (2016). Copper phytoaccumulation and tolerance by seedlings of native Brazilian trees. Environmental Engineering Science, 33(3), 176-184. 
Mateos-Naranjo, E., Andrades-Moreno, L., Cambrollé, J., \& Perez-Martin, A. (2013). Assessing the effect of copper on growth, copper accumulation and physiological responses of grazing species Atriplex halimus: ecotoxicological implications. Ecotoxicology and Environmental Safety, 90, 136-142.

Nunes, C., Araújo, S. S., Silva, J. M., Fevereiro, P., \& Silva, A. B. (2009). Photosynthesis light curves: a method for screening water deficit resistance in the model legume Medicago truncatula. Annals of Applied Biology, 155(3), 321-332.

Pinheiro, D. G., Streck, N. A., Richter, G. L., Langner, J. A., Winck, J. E. M., Uhlmann, L. O., \& Zanon, A. J. (2014). Soil water threshold for transpiration and leaf growth in cassava plants in two water deficit periods. Revista Brasileira de Ciência do Solo, 38(6), 1740-1749.

Shi, X., Zhang, X., Chen, G., Chen, Y., Wang, L., \& Shan, X. (2011). Seedling growth and metal accumulation of selected woody species in copper and lead/zinc mine tailings. Journal of Environmental Sciences, 23(2), 266-274.

Silva, N. D. G., Cholewa, E., \& Ryser, P. (2012). Effects of combined drought and heavy metal stresses on xylem structure and hydraulic conductivity in red maple (Acer rubrum L.) Journal of Experimental Botany, 63(16), 5957-5966.

Silva, R. F. D., Ros, C. O. D., Scheid, D. L., Grolli, A. L., Marco, R. D., \& Missio, E. L. (2015). Copper translocation and tolerance in seedlings of tree species grown in contaminated soil. Revista Brasileira de Engenharia Agrícola e Ambiental, 19(11), 1093-1099.

Souza, T. D., Castro, E. D., Pereira, F. J., Parentoni, S. N., \& Magalhães, P. C. (2009). Morpho-anatomical characterization of root in recurrent selection cycles for flood tolerance of maize (Zea mays L.) Plant Soil and Environment, 55(11), 504-510.

Souza, T. C. D., Magalhães, P. C., Pereira, F. J., Castro, E. M. D., Silva Junior, J. M. D., \& Parentoni, S. N. (2010). Leaf plasticity in successive selection cycles of 'Saracura' maize in response to periodic soil flooding. Pesquisa Agropecuária Brasileira, 45(1), 16-24.
Souza, T. C., De Castro, E. M., Magalhães, P. C., Alves, E. T., \& Pereira, F. J. (2012a). Early characterization of maize plants in selection cycles under soil flooding. Plant Breeding, 131(4), 493-501.

Souza, S. C. R., de Andrade, S. A. L., de Souza, L. A., \& Schiavinato, M. A. (2012b). Lead tolerance and phytoremediation potential of Brazilian leguminous tree species at the seedling stage. Journal of Environmental Management, 110, 299-307.

Souza, V. L., Almeida, A. A. F., Souza, J. S., Mangabeira, P. A. O., Jesus, R. M., Pirovani, C. P., Ahnert, D., Baligar, V. C., \& Loguercio, L. L. (2014). Altered physiology, cell structure, and gene expression of Theobroma cacao seedlings subjected to $\mathrm{Cu}$ toxicity. Environmental Science and Pollution Research, 21, 1217-1230.

Wahl, S., \& Ryser, P. (2000). Root tissue structure is linked to ecological strategies of grasses. New Phytologist, 148(3), 459-471.

Wang, Q. Y., Liu, J. S., \& Hu, B. (2016). Integration of copper subcellular distribution and chemical forms to understand copper toxicity in apple trees. Environmental and Experimental Botany, 123, 125-131.

Yruela, I. (2013). Transition metals in plant photosynthesis. Metallomics, 5(9), 1090-1109.

Zhang, L., Zhao, J., Duan, M., Zhang, H., Jiang, J., \& Yu, R. (2013). Inhibition of dsDNA-templated copper nanoparticles by pyrophosphate as a label-free fluorescent strategy for alkaline phosphatase assay. Analytical Chemistry, 85(8), 3797-3801.

Zhang, X., Zhang, X., Gao, B., Li, Z., Xia, H., Li, H., \& Li, J. (2014). Effect of cadmium on growth, photosynthesis, mineral nutrition and metal accumulation of an energy crop, king grass (Pennisetum americanum $\times P$. purpureum). Biomass and Bioenergy, 67, 179-187. 